\title{
THE EFFECTS OF ALTHESIN AND THIOPENTONE ON SYMPATHETIC AND BAROREFLEX ACTIVITY
}

\author{
J.E. Mackenzie, J.C. McGrath, J.-P. Téthault ${ }^{\circ}$ and R.A. Millar $\nmid$
}

ANAESTHESIA with the steroid agent Althesin is usually associated with reductions in arterial blood pressure. ${ }^{1-7}$

Depending on the rate of injection, the maximum depressant effect on blood pressure occurs usually after two or three minutes, while recovery requires approximately 15 minutes. ${ }^{8}$ The hypotension has been attributed to a reduction in peripheral resistance ${ }^{4,6,8}$ since cardiac output remains unaltered. ${ }^{3,10}$ Although myocardial contractility ${ }^{11}$ and stroke volume $e^{4,12}$ are depressed, cardiac output remains constant due to a concomitant increase in heart rate. ${ }^{3,5,7,10,19,14}$

Large doses of Althesin prevent the reflex bradycadia in response to the pressor effect of adrenaline, suggesting that the baroreceptor reflex is impaired. ${ }^{14}$ As the pressor effects of adrenaline ${ }^{14}$ and methoxamine ${ }^{3}$ are unaffected by the drug, its action is unlikely to be a direct one on vascular smooth muscle.

We have investigated the effects of Althesin on central sympathetic discharge and baroreceptor pathways, to clarify their influence on the circulatory responses observed.

\section{Methods}

Male New Zealand white rabbits weighing 2.8 to $3.5 \mathrm{~kg}$ were anaesthetized with pentobarbitone, or were decerebrated. The latter procedure was carried out under anaesthesia with 3 per cent halothane in oxygen, following early insertion of a tracheal cannula. The accompanying arterial pressure drop restricted bleeding and rendered carotid clamping unnecessary. At least one hour was allowed to elapse after administration of halothane had been discontinued before the effects of Althesin or thiopentone were studied.

In intact rabbits anaesthesia was induced with pentobarbitone $30 \mathrm{mg} / \mathrm{kg}$ given initially through the marginal ear vein, subsequent maintenance doses of $4 \mathrm{mg} / \mathrm{kg}$ being administered every 40 minutes through a femoral vein cannula.

Following the preparatory period, gallamine $1 \mathrm{mg} / \mathrm{kg}$ was given intravenously every 40 minutes in all animals. Mechanical ventilation using a Harvard pump Model 613 with 100 per cent oxygen was adjusted to maintain end-tidal carbon dioxide at approximately 4 per cent as monitored with a Beckman LB-2 carbon dioxide analyzer. Arterial pressure was recorded from the femoral artery with a Bell and Howell transducer, and heart rate was obtained from the pressure channel by means of a Devices instantaneous ratemeter. These measurements were

University Department of Anaesthesia, Royal Infirmary, Glasgow, G4 OSF, Scotland.

Present addresses:

"Université de Sherbrooke, P.Q.

$\nmid$ Memorial University, St. John's, Newfoundland. 
displayed on a Devices MX-4 four-channel recorder. Rectal temperature was maintained at $38.5 \pm 0.5^{\circ}$ by mean of a Palmer homoeothermic blanket. Arterial $\mathrm{pH}$ was measured with an IL 213 meter, and maintained above 7.30.

Preganglionic cervical sympathetic activity was recorded from strands dissected from the central end of the divided left nerve using bipolar platinum electrodes. The signal was amplified by a Tektronix Type 122 preamplifier, displayed on a Type D12 oscilloscope, thence taken to a pulse height selector, whence the spikes (above noise) were counted on a Panax ratemeter. Mean sympathetic discharge rate was displayed on the Devices recorder, using a time constant of 1 to 3 seconds. In each experiment, $2 \mu \mathrm{g}$ adrenaline was given intravenously to establish that the multifibre sympathetic preparation was under baroreceptor control, studies being continued only if nerve activity was reduced by the resulting rise in arterial pressure.

The desheathed central end of the divided left aortic depressor nerve was placed over a pair of silver wire electrodes for stimulation by a Devices isolated output stage. Stimulation was supramaximal, using 0.1 msee pulses at $50 \mathrm{~Hz}$ for 20 seconds. In all rabbits, the right aortic depressor nerve was also divided.

In six animals both vagi were divided in the neck and the desheathed peripheral end of the left nerve was placed on silver electrodes to allow supramaximal stimulation ( 0.1 msec pulse width, $5 \mathrm{~Hz}$ for 20 seconds).

Althesin or thiopentone was given intravenously, in progressively increasing doses, at least 30 minutes being allowed to elapse between each injection to ensure recovery to previous control levels.

The quantities of Althesin and thiopentone required to produce anaesthesia were determined by injections of the drugs into conscious rabbits through the marginal ear vein.

Drugs used were:

adrenaline acid tartrate (Macarthys)

gallamine triethiodide (May and Baker)

pentobarbitone sodium (Abbott)

althesin (Glaxo Laboratories; preparation composed of alphaxalone 0.9 per cent and alphadolone acetate 0.3 per cent $\mathrm{w} / \mathrm{v}$ in a solvent of polyoxyethylated castor oil 20 per cent in saline; doses are stated in $\mathrm{ml} / \mathrm{kg}$

thiopentone (Intraval sodium(i)) (May and Baker).

In order to assess possible effects of the solvent in Althesin, volumes equivalent to each dose level were given to two decerebrate and two pentobarbitone-anaesthetized rabbits. Other animals received a single injection of solvent equivalent to the largest volume of althesin used.

The data were analyzed for significance by the use of Student's " $t$ " test. The term "significant" in this report relates to $\mathrm{P}$ values of $<0.05$, by paired comparisons.

\section{Althesin}

\section{Results}

Anaesthesia was produced in conscious rabbits with Althesin $0.1-0.2 \mathrm{ml} / \mathrm{kg}$, which caused transient depression of arterial pressure and respiratory rate. The 
(a)Althesin

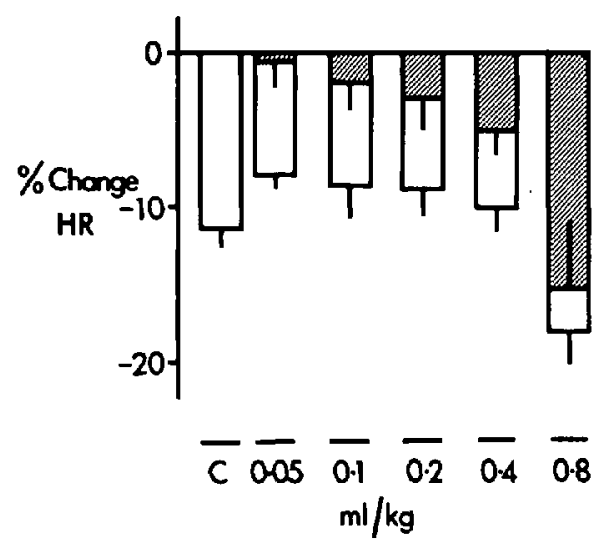

(b) Thiopentone

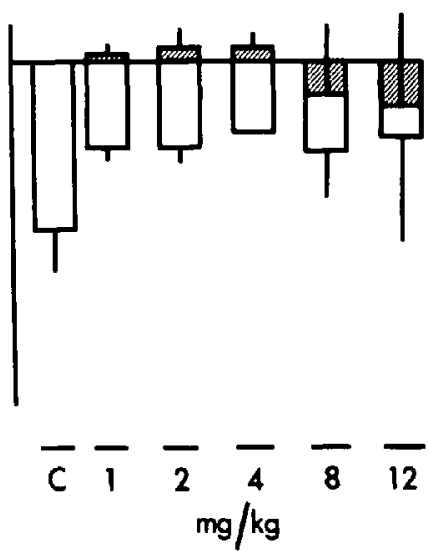

Ficure 1. Effects of Althesin and thiopentone on the heart rate (HR) component of the baroreceptor reflex in decerebrate rabbits. Shaded areas represent the change in HR two minutes after intravenous administration of the drug. Open areas represent the additional effect of depressor nerve stimulation, also at two minutes after administration. The changes are calculated as percentages of the pre-injection control levels. $(a)$ Althesin $(n=5),(b)$ thiopentone $(n=6)$. In each graph the control reflex is indicated at C. Bars indicate S.E.

(a)Althesin

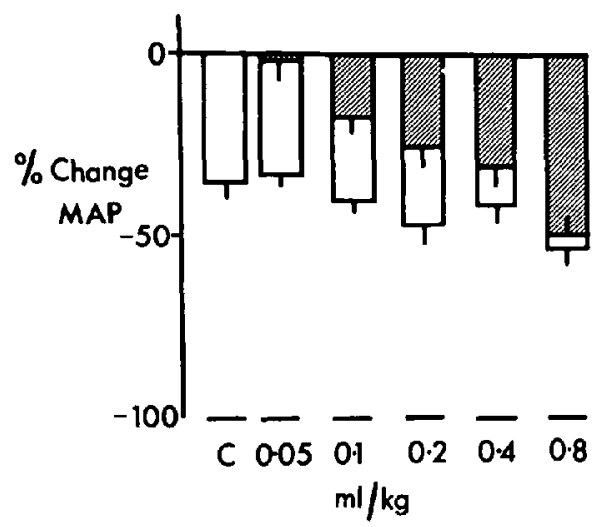

(b)Thiopentone

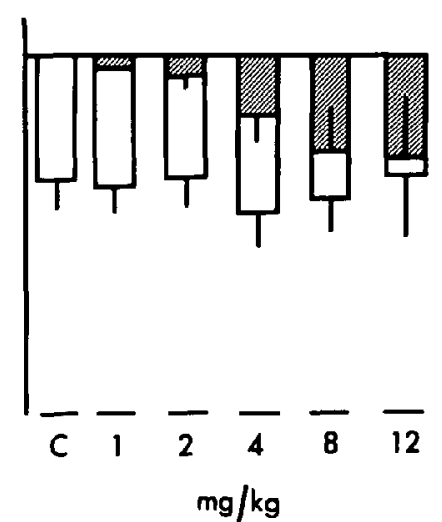

Figure 2. Effects of Althesin and thiopentone on the mean arterial pressure (MAP) component of the baroreceptor reflex in decerebrate rabbits. Shaded areas represent the change in MAP two minutes after intravenous administration of the drug. Open areas represent the additional effect of depressor nerve stimulation, also at two minutes after administration. The changes are calculated as percentages of the pre-injection control levels. $(a)$ Althesin $(n=5),(b)$ thiopentone $(n=6)$. In each graph the control reflex is indicated at C. Bars indicate S.E.

dose range studied in sequence in the present experiments was 0.05 to $0.80 \mathrm{ml} / \mathrm{kg}$, full recovery requiring approximately 30 minutes between each injection.

The responses (mean \pm S.E.) of heart rate, mean arterial pressure, and preganglionic sympathetic activity to Althesin in five decerebrate animals are shown respectively in the left sections of Figures 1,2 and 3. The shaded areas indicate the percentage change from the level just before injection, two minutes after the drug had been given. In these decerebrate rabbits, mean arterial pressure and heart rate at the start of the experiment averaged $77( \pm 10) \mathrm{mm} \mathrm{Hg}$ and $306( \pm 11)$ beats/min respectively, levels which were similar to those in animals anaesthetized 
(a)Althesin

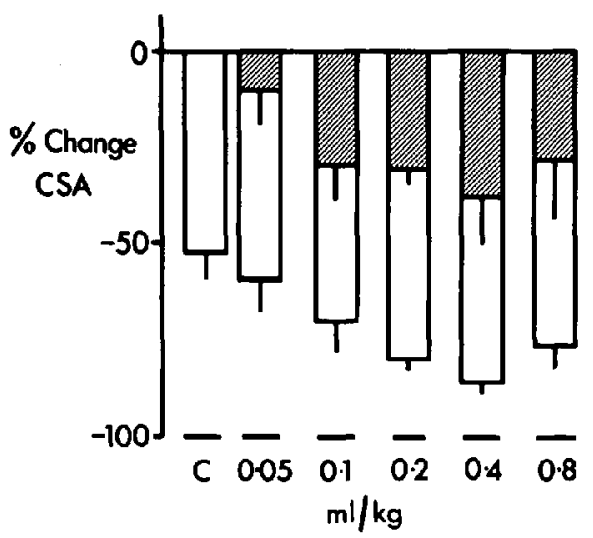

(b) Thiopentone

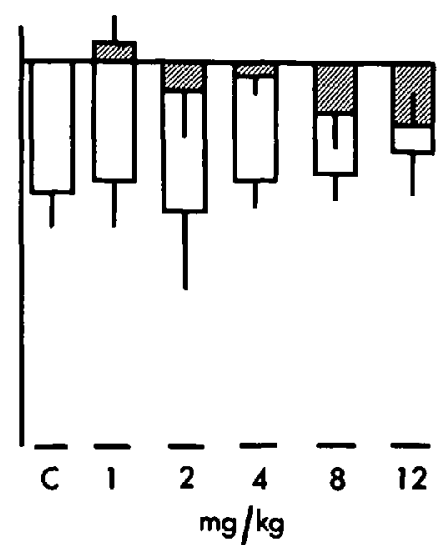

FIgunE 3. Effects of Althesin and thiopentone on the cervical sympathetic activity (CSA) component of the baroreceptor reflex in decerebrate rabbits. Shaded areas represent the change in CSA two minutes after intravenous administration of the drug. Open areas represent the additional effect of depressor nerve stimulation, also at two minutes after administration. The changes are calculated as percentages of the pre-injection control levels. $(a)$ Althesin $(n=5),(b)$ thiopentone $(n=6)$. In each graph the control reflex is indicated at C. Bars indicate S.E.

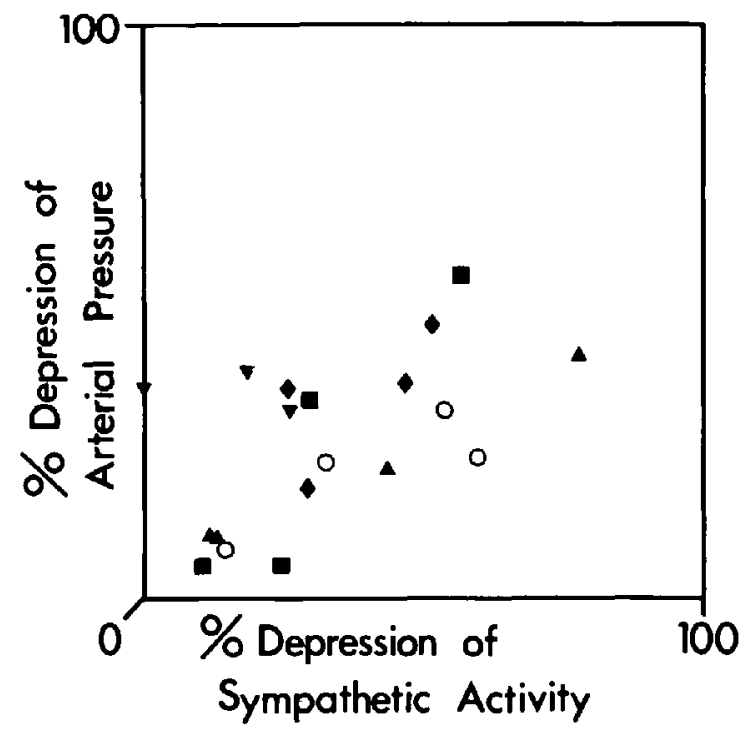

FICURE 4. Plot of simultaneous changes in arterial pressure and cervical sympathetic activity two minutes after injection of Althesin. Results from each of five decerebrate rabbits are represented by different symbols. Doses of Althesin ranged from 0.05 to $0.8 \mathrm{ml} / \mathrm{kg}$.

lightly with pentobarbitone. Figure I shows that the effects of Althesin on heart rate were small, a statistically significant reduction being measured with 0.4 and $0.8 \mathrm{ml} / \mathrm{kg}$. Mean arterial pressure (Figure 2 ) and sympathetic discharge (Figure 3) were reduced significantly by all doses except the lowest of $0.05 \mathrm{ml} / \mathrm{kg}$.

Figure 4 relates the depressant action of Althesin on sympathetic activity and arterial pressure; with the exception of experiment $(\nabla)$, the responses appear to be associated or correlated.

A representative record of the effects of $0.2 \mathrm{~m} / \mathrm{kg}$ Althesin is shown in Figure 5 . 

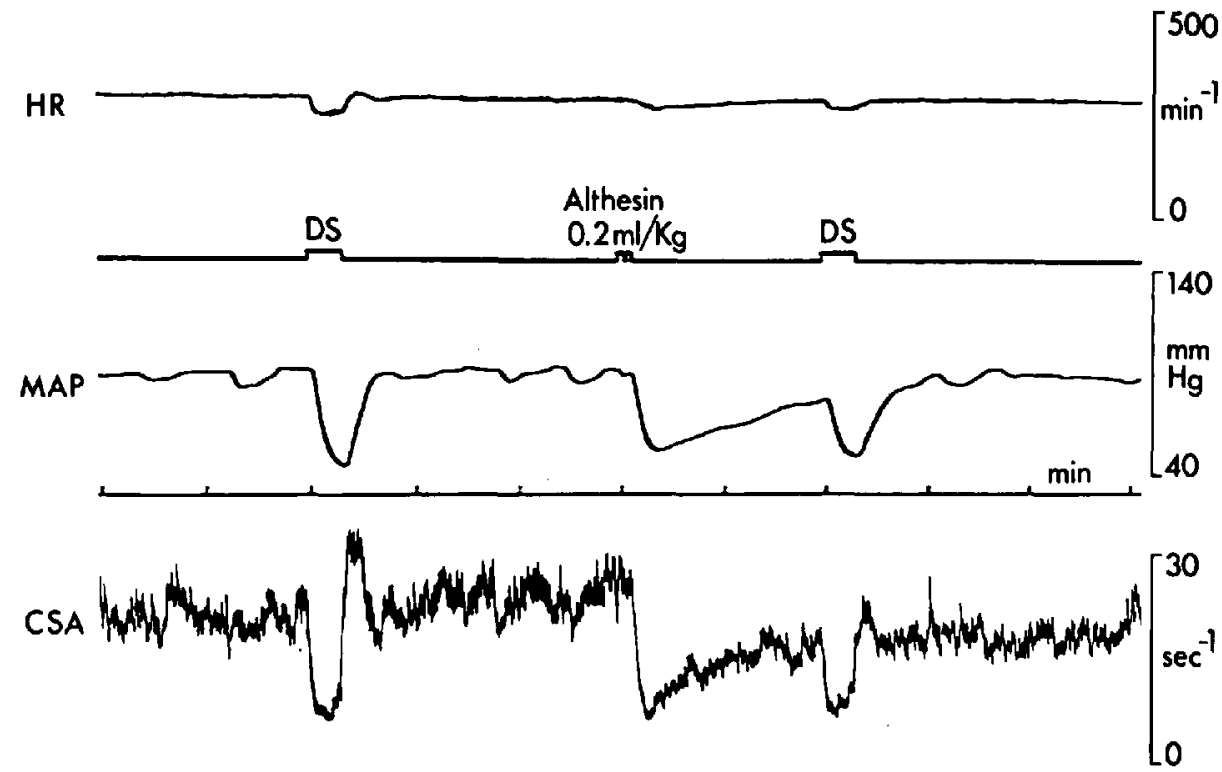

FIGURE 5. Effects of Althesin $0.2 \mathrm{ml} / \mathrm{kg}$ on heart rate (HR), mean arterial pressure (MAP), and cervical sympathetic activity (CSA) in a decerebrate rabbit. Marker trace indicates stimulation of the left aortic depressor nerve (DS).

In the presence of light background anaesthesia with pentobarbitone the responses to Althesin were more pronounced and variable and are shown in Figure 6 (shaded areas). Significant reductions in heart rate and mean arterial pressure occurred with 0.4 and $0.8 \mathrm{ml} / \mathrm{kg}$. Sympathetic activity was depressed significantly by Althesin at all dose levels when given with a background of light pentobarbitone anaesthesia.

The effects of Althesin on the three components of the baroreceptor reflex in decerebrate animals are shown in the left section of Figures 1,2 and 3. The unshaded areas represent the percentage reductions in heart rate, mean arterial pressure and preganglionic activity induced by depressor nerve stimulation at the start of the experiment and two minutes after injection of each dose. The "control" measurements to which these reductions relate are those just before each injection of Althesin. While it may be assumed that inhibition of the reflex is shown by a reduction in the open areas, it is emphasized that this effect is superimposed on the depressant action of the drug per se (shaded area). Because of this lowered baseline prior to depressor stimulation, a statistical assessment of "percentage baroreceptor inhibition," or similar deductions, have been avoided deliberately. From Figure 1, however, which shows that the drug itself has minimal effects on heart rate except in the highest dose, it is concluded that even $0.05 \mathrm{ml} / \mathrm{kg}$ Althesin depresses this component of the baroreceptor reflex. Figure 3 also indicates clearly that the drug does not inhibit the fall in preganglionic sympathetic activity induced by baroreceptor stimulation. Changes in the arterial pressure component, illustrated in Figure 2, suggest an inhibitory action only if the effect of the drug on the background level is excluded.

In animals given pentobarbitone, in which decreases in heart rate, arterial pres- 
ALTHESIN ( Pentobarbitone)
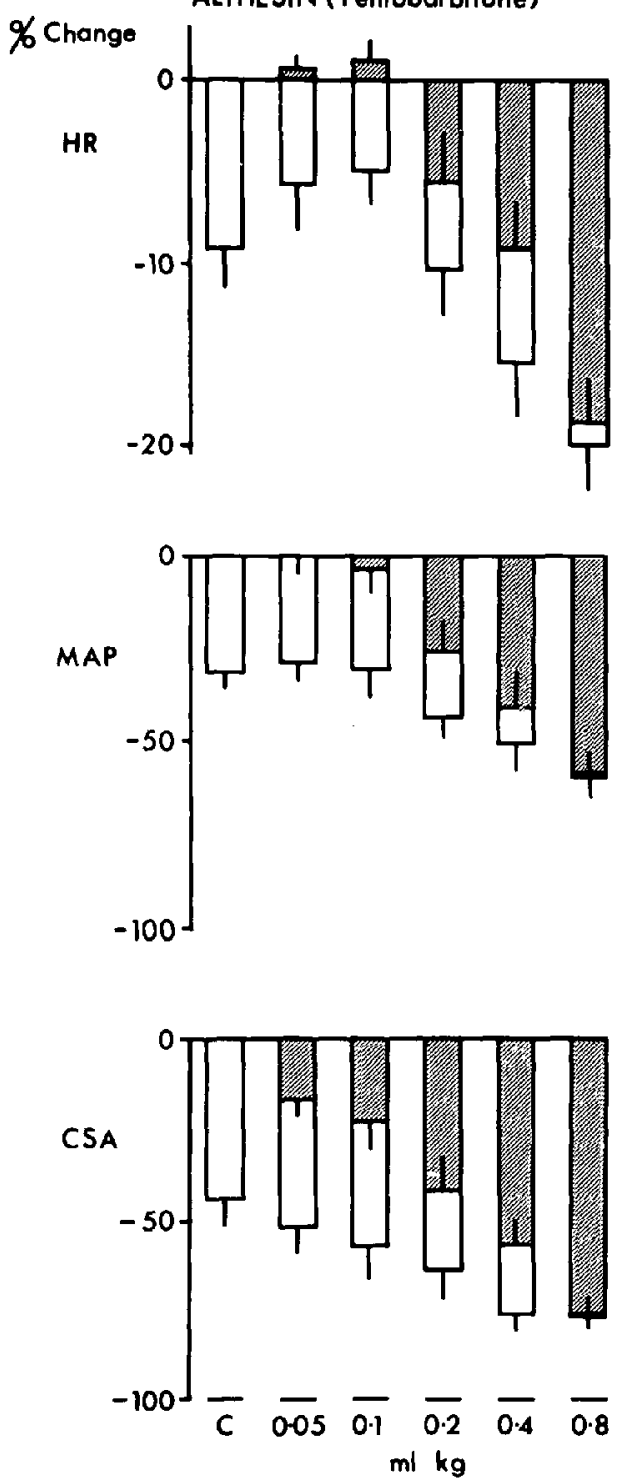

Figure 6. Effects of Althesin in rabbits lightly anaesthetized with pentobarbitone. Shaded areas represent the change in (a) heart rate (HR), (b) mean arterial pressure (MAP), and (c) cervical sympathetic activity (CSA) two minutes after intravenous administration of the drug. Open areas represent the additional effect of depressor nerve stimulation, also at two minutes after administration. The changes are calculated as percentages of the pre-injection control levels. $(n=7)$. In each graph the control reflex is indicated at C. Bars indicate S.E.

sure and sympathetic activity caused by Althesin were more pronounced (Figure 6 ), an accurate quantitative assessment of change in the magnitude of the baroreceptor reflex is still more complex, and again has been avoided. However, the results were similar to those in the decerebrate animals. Inhibition of the heart rate component, shown by a reduced open area in the top section of Figure 6, occurred with the lowest doses of Althesin $(0.05$ and $0.1 \mathrm{ml} / \mathrm{kg}$ ). 


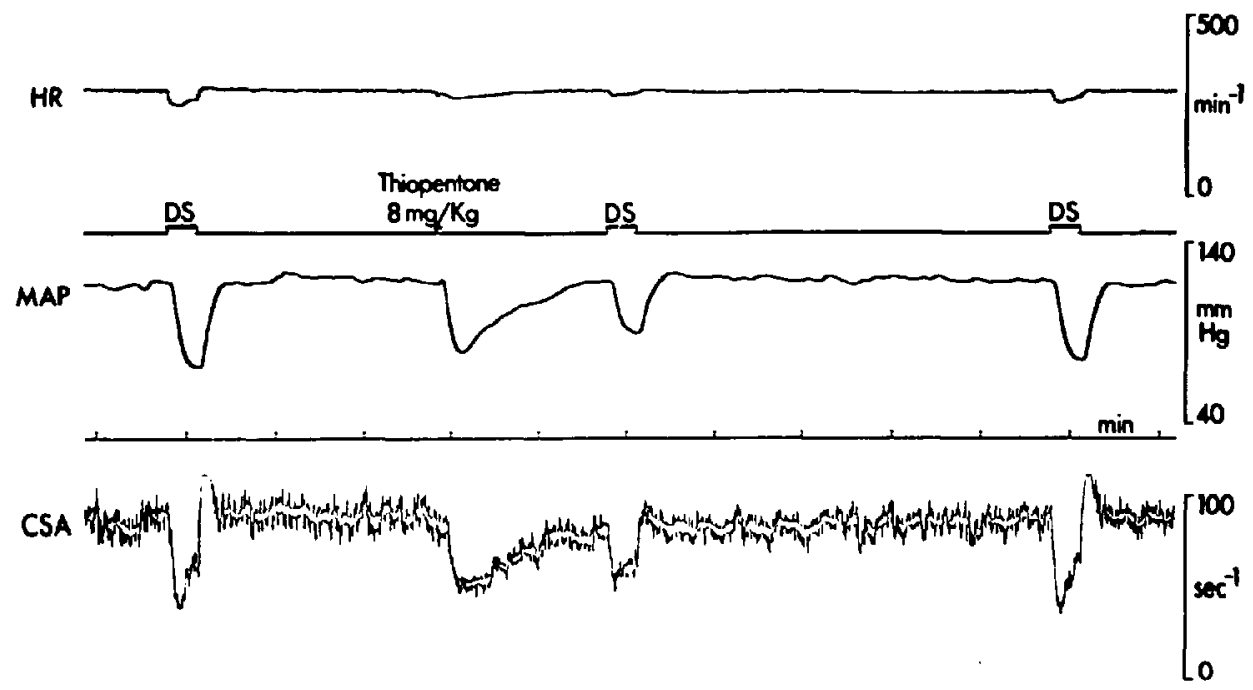

FIGURE 7. Effects of intravenous thiopentone $8 \mathrm{mg} / \mathrm{kg}$ on heart rate (HR), mean arterial pressure (MAP), and cervical sympathetic activity (CSA) in a decerebrate rabbit. Marker trace indicates stimulation of the left aortic depressor nerve (DS).

In volumes equivalent to those used with Althesin the solvent (cremophor EL), when injected alone, had no distinct effect on the three measurements.

\section{Thiopentone}

In conscious animals, anaesthesia was produced with 4 to $8 \mathrm{mg} / \mathrm{kg}$ thiopentone.

The drug had little effect on heart rate (shaded areas in right section of Figure 1), while mean arterial pressure and sympathetic activity were reduced (Figures 2 and 3 ). Because of variability in the six decerebrate animals studied, none of these changes was statistically significant.

With even the lowest dose $(1 \mathrm{mg} / \mathrm{kg})$ of thiopentone, there was a marked reduction in the heart rate component of the baroreceptor reflex (Figure 1, open area of right section). The responses of sympathetic activity and mean arterial pressure to baroreceptor stimulation were less obviously affected (Figures 2 and 3), except with thiopentone $8 \mathrm{mg} / \mathrm{kg}$ and higher, when some attenuation of these components of the reflex was apparent after the drug per se had produced relatively small reductions.

Figure 7, from one experiment, shows little depression of heart rate or mean arterial pressure two minutes after thiopentone injection, whereas there is some inhibition of the reflex responses, especially of heart rate.

Because of an initially changing baseline, effects on the baroreceptor reflex could not be tested reliably until two minutes after injection.

\section{ROLE OF THE VAGUS}

In contrast to the bradycardia normally elicited, depressor nerve stimulation, caused only a small fall in heart rate after bilateral vagotomy in decerebrate or pentobarbitone-anaesthetized animals, indicating that this component of the reflex was mediated mainly by efferent vagal activity. 


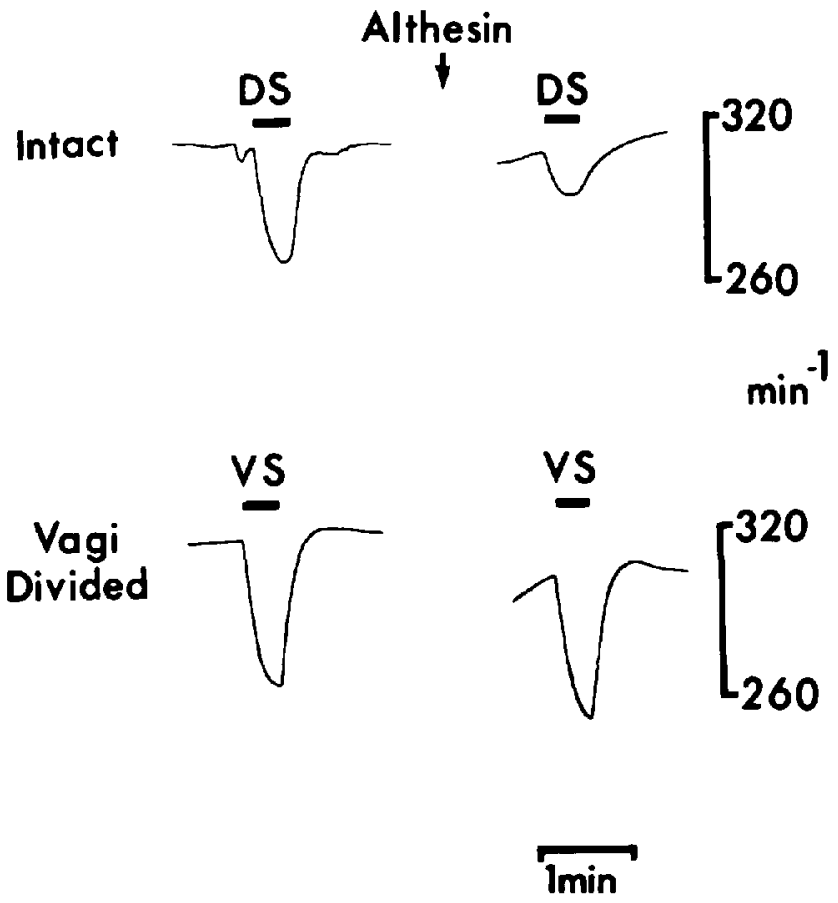

Frgure 8. Effect of intravenous Althesin $0.2 \mathrm{ml} / \mathrm{kg}$ on the heart rate component of the depressor reflex in a decerebrate rabbit. DS - stimulation of the left depressor nerve ( $50 \mathrm{~Hz}, 20$ seconds). VS - stimulation of the peripheral end of the divided left vagus ( $15 \mathrm{~Hz}, 20$ seconds). Upper traces - vagi intact. Lower traces - following bilateral vagotomy. Marker indicates 20-second period of stimulation.

When the distal end of the divided left vagus nerve was stimulated electrically, bradycardia was of similar magnitude to that evoked by depressor nerve stimulation (Figure 8). Neither Althesin $(0.2 \mathrm{ml} / \mathrm{kg}$ ) nor thiopentone $(8 \mathrm{mg} / \mathrm{kg}$ ) reduced this response (Figure 8 ), indicating that the attenuation of the reflex attributed to the drugs was due not to an atropine-like action at the neuroeffector junction, or to an effect on parasympathetic ganglia, but probably to a reduced vagal outflow of central origin.

\section{Discussion}

These results show that in the mechanically ventilated rabbit, both Althesin and thiopentone produce a roughly parallel reduction of preganglionic sympathetic activity and mean arterial pressure. In view of the uncertainty about the equivalent anaesthetic (or cardiovascular) "potency" of the doses of Althesin and thiopentone which were employed here, the relative actions of the two agents cannot be compared with accuracy. However, the data confirm previous observations ${ }^{15,16}$ that short-acting barbiturates depress sympathetic activity and arterial pressure in lightly anaesthetized and decerebrate cats, and show that Althesin may act similarly. Thus, the fall in arterial pressure caused by Althesin, which has been attributed previously in man largely to an effect on peripheral resistance, ${ }^{9,4,6}$ may be due in part to a reduction in central sympathetic activity, as has been suggested for the barbiturates. 
While Althesin showed similar effects in decerebrate animals and in those given pentobarbitone previously, depression of sympathetic activity was more pronounced in the presence of the background anaesthetic, presumably due to interaction of the two agents. Although decerebration eliminates this possibility, it involves removal of the hypothalamus and higher cerebral neurones which are concerned in neurocirculatory control.

All the intravenous anaesthetics which have been investigated while mechanical ventilation is employed have been found to inhibit directly recorded preganglionic sympathetic discharge. The list includes thiopentone, ${ }^{15,16}$ Althesin (present study), methohexitone, ${ }^{16}$ pentobarbitone, ${ }^{17,15}$ and ketamine. ${ }^{18}$ Unlike the others, ketamine is well known to cause pressor effects although not under all experimental conditions. ${ }^{19}$

Neither Althesin nor thiopentone produced any substantial inhibition of baroreceptor-mediated reductions in sympathetic activity or arterial pressure. In some experiments, brief attenuation of these reflexes could be detected immediately after the injection of thiopentone $8 \mathrm{mg} / \mathrm{kg}$ or more. This may agree with observations made in cats, ${ }^{16}$ although the use of 50 per cent nitrous oxide as a background "anaesthetic", ${ }^{20,21}$ and of aortic nerve stimulation in this species, ${ }^{22}$ raises serious questions.

Evidence was obtained here that both Althesin and thiopentone in the lowest doses used inhibited the heart rate component of the baroreceptor reflex two minutes after injection. A similar finding was obtained in a recent study of ketamine. ${ }^{18}$ In addition, pentobarbitone $6 \mathrm{mg} / \mathrm{kg}$ (which is higher than the regular background doses employed in our experiments) depresses this response of heart rate and has relatively little effect on the sympathetic and pressure components (unpublished observations ). Other workers have described inhibition of the bradycardia induced by vasopressor injection by thiopentone in $\operatorname{man}^{23}$ and by Althesin in the cat. ${ }^{14}$ In similar investigations propanidid caused no change. ${ }^{24,14}$ A special sensitivity of this response to intravenous anaesthetics could be attributable to central or peripheral vagal effects. With ketamine ${ }^{18}$ and with Althesin or thiopentone in the present study, a peripheral vagal action was not detected. The evidence is, therefore, that central vagal pathways involved in the control of heart rate may be especially sensitive to anaesthetics; one conjecture could be that a greater number of synaptic connections are involved than in the control of sympathetic discharge. An apparently selective action of the intravenous anaesthetics could derive from their more rapid, less prolonged effects in comparison to inhalation agents.

When assessed by depressor nerve stimulation in the rabbit, ${ }^{25}$ the inhalation agents cyclopropane, diethyl ether and halothane (in descending order of "effect") markedly inhibited the sympathetic and arterial pressure components of the baroreceptor reflex. In that study, a selective action of the inhalation anaesthetics on the heart rate component was not sought, nor studied specifically, although inhibition was apparent. ${ }^{25}$ - In man, nitrous oxide and halothane partially blocked the decrease in heart rate caused by phenylephrine injection..$^{23}$ However, in another investigation, methoxyflurane was reported to exert no inhibition of the decrease in heart rate evoked by phenylephrine. ${ }^{26}$

${ }^{\circ}$ See Figure 6 of this reference. 
Both thiopentone and Althesin reduce arterial pressure and increase heart rate in man. ${ }^{6}$ While a selective blockade of central vagal pathways by intravenous anaesthetics could account for a relatively higher heart rate at a given arterial pressure, the clinical implications of such reflex "resetting" require further examination.

\section{Summary}

In decerebrate rabbits which were mechanically ventilated, both Althesin and thiopentone depressed preganglionic sympathetic activity and arterial pressure. Conduction through central baroreceptor pathways, tested by depressor nerve stimulation, showed a selective inhibition of the heart rate response by both agents. Effects were similar with Althesin injection in animals which were lightly anaesthetized with pentobarbitone. Depression of the arterial pressure and sympathetic components of the baroreceptor reflex was apparent only with high doses.

\section{RÉSUMÉ}

Chez le lapin décérébré ventilé mécaniquement, l'althesin comme le thiopental diminue l'activité sympathique préganglionnaire et la pression artérielle. L'étude de la conduction des barorécepteurs centraux par stimulation des nerfs dépresseurs, montre une inhibition sélective de la réponse chronotrope cardiaque par ces deux agents. Les effets sont semblables avec une injection d'althesin administrée à des animaux légèrement anesthésiés au thiopentone. La diminution de la pression artérielle et la dépression des éléments sympathiques du réflexe barorécepteur n'est pas apparent qu'aux très fortes doses.

\section{ACKNOWLEDGMENTS}

Excellent technical assistance was provided by Mr. G.M. McCreaddie. We are grateful to Glaxo Laboratories Limited for providing althesin solvent. This work was supported by the Medical Research Council. Dr. J.C. McGrath held a Wellcome Trust Interdisciplinary Fellowship. Dr. J.-P. Tétrault received a grant from the Medical Research Council of Quebec.

\section{REFERENCES}

1. Steward, D.J. The effect of CT 1341 on cerebral blood How and intracranial pressure. Proceedings of the Fifth World Congress of Anaesthesiologists, Kyoto, p. 124. Amsterdam: Excerpta Medica (1972).

2. Turner, J.M., Cononeos, N.J., Gibson, R.M., Powell, D., Ness, M.A., \& McDowall, D.G. The effect of Althesin on intracranial pressure in man. Br. J. Anaesth. 45: 168 (1973).

3. Coleman, A.J., Downing, J.W., Leary, W.P., Moyes, D.G., \& Styles, M. The immediate cardiovascular effects of Althesin (Glaxo CT 1341), a steroid induction agent, and thiopentone in man. Anaesthesia 27: 373 (1972).

4. Clarke, R.S.J., Montcomery, S.J., Dundee, J.W., \& Bovill, J.G. Clinical studies of induction agents. XXXIX, CT 1341, a new steroid anaesthetic. Br. J. Anaesth. 43: 947 (1971).

5. Miller, D.C., Bradfond, E.M.W., \& Campbell, D. Haemodynamic effects of Althesin in poor-risk patients. Postgrad. Med. J. 48, Supplement 2: 133 (1972). 
6. Savege, T.M., Foley, E.I., Ross, L., \& Maxwell, M.P. A comparison of the cardiorespiratory effects during induction of anaesthesia of Althesin (CT 134l) with thiopentone and methohexitone. Postgrad. Med. J. 48, Supplement 2; 66 (1972).

7. Benke, A., Gogolak, G., Stumpf, C.H., \& Tschakalof F, C.H. Althesin and hydroxydione: comparative laboratory and clinical investigations. Postgrad. Med. J. 48, Supplement 2: 120 (1972).

8. Pickenod, V.W.A., McDowall, D.G., Cononeos, N.J., \& Keaney, N.P. Effect of Althesin on cerebral perfusion, cerebral metabolism and intracranial pressure in the anaesthetized baboon. Br. J. Anaesth. 44: 751 (1972).

9. Jones, J., PAyne, J.P., \& Perry, I.R. Some clinical pharmacological effects of Althesin (CT 1341). Br. J. Pharmacol. 46: 553P (1972).

10. Savege, T.M., Foley, E.I., Coultas, R.J., Walton, B., Strunin, L., Simpson, B.R., \& ScotT, D.F. CT 1341: some effects in man. Anaesthesia 26: 402 (1971).

11. FoEx, P. \& Prys-Roberts, C. Pulmonary haemodynamics and myocardial effects of Althesin (CT 1341) in the goat. Postgrad. Med. J. 48, Supplement 2: 24 (1972).

12. Prys-Robents, C., Fö̈x, P., \& Biro, G.P. Cardiovascular responses of hypertensive patients to induction of anaesthesia with Althesin. Postgrad. Med. J. 48, Supplement 2: 80 (1972).

13. Child, K.J., Davis, B., Dodds, M.G., \& Twissell, D.J. Anaesthetic, cardiovascular and respiratory effects of the new steroidal agent CT 1341: a comparison with other intravenous anaesthetic drugs in the unrestrained cat. Br. J. Pharmacol 46:189 (1972).

14. Donds, M.G., \& Twissell, D.J. Effect of Althesin (CT 1341) on circulatory responses to adrenaline and on halothane-adrenaline cardiac dysrhythmias in the cat. Postgrad. Med. J. 48, Supplement 2: 17 (1972).

15. Millar, R. A., Warden, J.C., Cooperman, L.H., \& Price, H.L. Further studies of sympathetic actions of anaesthetics in intact and spinal animals. Br. J. Anaesth. 42: 366 (1970).

16. Skovsted, P., Price, M.L., \& Price, H.L. The effects of short-acting barbiturates on arterial pressure, preganglionic sympathetic activity and barostatic reflexes. Anesthesiology 33:10 (1970).

17. Millat, R.A. \& Biscoe, T.J. Preganglionic sympathetic activity and the effects of anaesthetics. Br. J. Anaesth. $37: 804$ (1965).

18. McGrath, J.C., MacKenzie, J.E., \& Millar, R.A. Effects of ketamine on central sympathetic discharge and the baroreceptor reflex during mechanical ventilation. Br. J. Anaesth. 47: 114 (1975).

19. McGrath, J.C., MacKenzie, J.E., \& Millar, R.A. Circulatory responses to ketamine: dependence on respiratory pattern and background anaesthesia in the rabbit. $\mathrm{Br}$. J. Anaesth. 47:1149 (1975).

20. Russell, W.J. Nitrous oxide - is it an adequate anaesthetic? J. Physiol, 228: 20P (1973).

21. Steffey, E.P., Gillespie, J.R., Berry, J.D., Eger, E.I. II., \& Munson, E.S. Anesthetic potency ( $\mathrm{MAC}$ ) of nitrous oxide in the dog, cat and stump-tail monkey. J. Appl. Physiol., 36: $530(1974)$.

22. Gebmer, G.L. The central organization of the baroreceptor reflexes. Anesthesiology 32 : $193(1970)$.

23. Bhistow, J.D., Phys-Roberts, C., Fischen, A., Pickening, T.G., \& Sleight, P. Effects of anesthesia on baroreflex control of heart rate in man. Anesthesiology 31: 422 (1969).

24. Bristow, J.D., Prys-Roberts, C., \& Fisher, A. Quantification of baroreceptor reflexes during anaesthesia in man. Br. J. Anaesth. 41: 556 (1969).

25. Biscoe, T.J. \& Millar, R.A. The effects of cyclopropane, halothane and ether on central baroreceptor pathways. J. Physiol. 184: 535 (1966).

26. Mirtler, G. \& WADE, J. The effect of methoxyflurane on baroreflex control of heart rate in man. Can. Anaesth. Soc. J. 19: 60 (1972). 